\title{
Pengaruh Penerapan E-Filling Perpajakan, Kualitas Pelayanan, Kesadaran Wajib Pajak, dan Sanksi Perpajakan pada Kepatuhan WPOP
}

\author{
I Putu Ardhian Janu Mahendra1 \\ Fakultas Ekonomi dan Bisnis \\ Universitas Udayana, Indonesia \\ Email: putuardian456@gmail.com
}

\author{
Ketut Budiartha ${ }^{2}$ \\ Fakultas Ekonomi dan Bisnis \\ Universitas Udayana, Indonesia
}

\begin{abstract}
ABSTRAK
Penelitian ini bertujuan untuk mengetahui Pengaruh penerepan e-filling, kualitas, kesadaran wajib pajak, dan sanksi perpajakan pada kepatuhan wajib pajak orang pribadi di KPP Pratama Denpasar Timur. Metode analisis data yang digunakan adalah regresi linier berganda. Hasil penelitian ini menunjukkan bahwa baiknya penerapane-filling, kualitas pelayanan, kesadaran wajib pajak, dan sanksi perpajakan berpengaruh signifikan pada kepatuhan wajib pajak orang pribadi yang terdaftar di KPP Pratama Denpasar Timur. Penelitian ini dapat dijadikan motivasi bagi KPP Prtama Denpasar Timur untuk dapat mempertahankan kualitas pelayanan yang baik bagi kepuasan dan kenyamanan wajib pajak untuk melaksanakan kewajiban perpajakannya.
\end{abstract}
Kata Kunci: Penerapan E-Filling; Kualitas Pelayanan; Kesadaran Wajib Pajak; Sanksi Perpajakan; Kepatuhan.

\section{Effects of Tax E-Filling Implementation, Service Quality, Taxpayer Awareness, and Tax Sanctions on Taxpayer Compliance}

\section{ABSTRACT}

This study aims to determine the effect of e-filling forwarding, quality, taxpayer awareness, and tax sanctions on individual taxpayer compliance at East Denpasar KPP. The data analysis method used is multiple linear regression. The results of this study indicate that the good application of e-filling, quality of service, awareness of taxpayers, and tax penalties have a significant effect on the compliance of individual taxpayers who are registered at the East Denpasar KPP. This research can be used as a motivation for KPT Prtama East Denpasar to be able to maintain good service quality for the satisfaction and comfort of taxpayers to carry out their tax obligations.

Keywords: $\quad$ Application of E-Filing; Service Quality; Taxpayer Awareness; Tax Sanctions; Obedience.

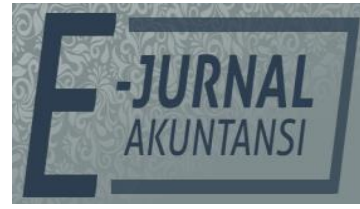

e-Jurnal Akuntansi e-ISSN 2302-8556

Vol. 30 No. 5

Denpasar, Mei 2020

Hal.1183-1195

Artikel Masuk:

9 Desember 2019

Tanggal Diterima: 7 Februari 2020 


\section{PENDAHULUAN}

Pajak didapat dari kontribusi masyarakat (wajib pajk) dengan menggunakan sistem self assessment. Sistem self assessment merupakan sebuah sistem reformasi yang dilakukan oleh Direktorat Jenderal Pajak. Sistem ini menggantikan sistem official assessment yang berlaku sebelumnya. Kepatuhan memenuhi kewajiban perpajakan secara sukarela merupakan tulang punggung self assessment system (Lai \& Choong, 2009). Sistem self assessment adalah sistem dimana Wajib Pajak diberi kepercayaan untuk menghitung dan melaporkan sendiri pajak yang terutang oleh Wajib Pajak, sedangkan petugas pajak sendiri bertugas untuk mengawasinya.

Pajak juga berfungsi untuk membatasi konsumsi masyarakat, memeratakan keadilan sosial kepada masyarakat dan untuk investasi pemerintah melalui APBN. Langkah pemerintah meningkatkan penerimaan pajak dalam Anggaran Pendapatan dan Belanja Negara (APBN) 2019 menjadi Rp 1.577,6 triliun tidak tepat. Sebab, bila berkaca pada 2018 lalu penerimaan pajak di bawah yang ditargetkan. Diketahui, penerimaan pajak pada 2018 hanya mencapai Rp 1.315,9 triliun atau sekitar 92,4 persen dari target yang ditetapkan sebesar Rp 1.424 triliun. Ajib Hamdani selaku Ketua Himpunan Pengusaha Muda Indonesia (Hipmi) Tax Center, menyatakan bahwa sejak 2019 penerimaan pajak tidak pernah mencapai target. Capaian ini juga menunjukkan bahwa wajib pajak di Indonesia masih banyak yang belum mengungkapkan harta kekayaan atau pun pendapatannya secara riil sehingga kepatuhan wajib pajak di Indonesia juga perlu ditingkatkan. Realisasi Penerimaan Negara pada tahun 2015-2018 dapat dilihat pada Tabel 1.

Tabel 1. Realisasi Penerimaan Negara Tahun 2015-2018 (Triliunan Rupiah)

\begin{tabular}{lll}
\hline Penerimaan Pajak & Penerimaan Bukan Pajak & Total \\
\hline $1.240 .418,9$ & 255628,4 & $1.496 .047,2$ \\
$1.284 .970,1$ & $261.967,3$ & $1.546 .937,4$ \\
$1.343 .529,8$ & $311.216,3$ & $1.654 .746,1$ \\
$1.548 .485,0$ & $349.158,3$ & $1.897 .643,3$ \\
\hline
\end{tabular}

Sumber: www.bps.go.id, 2019

Berdasarkan Tabel 1. menunjukan bahwa penerimaan dari sektor pajak lebih besar daripada penerimaan sektor non pajak, hal ini membuktikan bahwa kontribusi pajak signifikan dan terus meningkat dari tahun ke tahun pada sumber penerimaan Negara.

Melihat peranan pajak yang begitu penting untuk pembangunan insfrastruktur negara, maka dari itu Pemerintah melalui Direktorat Jenderal Pajak (DJP) berusaha meningkatkan penerimaan pajak dengan melakukan perluasan subjek dan objek pajak. Pemerintah juga memasang target penerimaan pajak untuk setiap Kantor Pelayanan Pajak di seluruh Indonesia, salah satunya di KPP Pratama Denpasar Timur. Kantor Pelayanan Pajak (KPP) Pratama Denpasar Timur merupakan instansi yang menangani pembayaran Pajak Penghasilan (PPh) wajib pajak orang pribadi maupun badan di Denpasar.

Menurut Idawati (2012) menyebutkan bahwa pengarsipan elektronik atau pengajuan online pengembalian pajak adalah istilah umum untuk pengarsipan elektronik atau elektronik pengajuan atau deklarasi pengembalian pajak secara elektronik melalui penyerahan data pajak ke otoritas perpajakan berbentuk 
format file di komputer melalui koneksi internet. Laihad, (2013) menunjukkan bahwa wajib pajak berpengaruh positif terhadap penggunaan $e$-filling sehingga dapat meningkatkan efektivitas dan efisien dalam hal pelaporan pajak.

Adanya sistem pelaporan pajak dengan menggunakan $e$-filing dapat memudahkan Wajib Pajak. Wajib Pajak dapat melaporkan SPT-nya 24 jam selama 7 hari. Hal ini berarti wajib pajak dapat melaporkan SPT-nya meskipun pada hari libur. Sistem ini sangat bermanfaat untuk wajib pajak yang tidak melapokan SPT-nya dengan alasan sibuk.

Tabel 2. Jumlah SPT Tahunan Wajib Pajak Orang Pribadi yang Menggunakan E-Filling 2015-2017

\begin{tabular}{llll}
\hline Tahun & 2015 & 2016 & 2017 \\
\hline $\begin{array}{l}\text { SPT Tahunan Wajib Pajak Orang Pribadi } \\
\text { yang Menggunakan E-Filling }\end{array}$ & 26.707 & 32.795 & 34.035 \\
\hline
\end{tabular}

Sumber: KPP Pratama Denpasar Timur, 2019

Jumlah SPT tahunan wajib pajak orang pribadi yang menggunakan $e$ filling di KPP Pratama Denpasar Timur berdasarkan Tabel 2. tahun 2015 sampai tahun 2017 mengalami peningkatan. Hal ini membuktikan penggunaan $e$-filling dalam melaporkan SPT nya oleh wajib pajak orang pribadi sangat efektif.

Kualitas pelayanan juga dapat meningkatkan kepatuhan wajib pajak. Kualitas adalah keseluruhan ciri-ciri dan karakteristik dari suatu produk atau jasa menyangkut kemampuan untuk memenuhi kebutuhan yang telah ditentukan atau yang bersifat paten. Pelayanan adalah suatu proses bantuan kepada orang lain dengan cara-cara tertentu yang memerlukan kepekaan dan hubungan interpersonal agar tercipta kepuasan dan keberhasilan mendefinisikan kualitas pelayanan sebagai kemampuan organisasi untuk memenuhi atau melebihi harapan pelanggan. Standar kualitas pelayanan prima kepada wajib pajak akan terpenuhi bilamana sumber daya manusia melaksanakan tugasnya secara professional, disiplin, dan transparan.

Chau \& Leung (2009) menyebutkan ancaman sanksi yang kurang tegas terhadap wajib pajak cenderung mengabaikan kewajiban perpajakannya, dengan demikian kesadaran wajib pajak terhadap aturan-aturan pajak yang ada sangat menentukan berhasil tidaknya penerapan aturan perpajakan. Penerimaan pendapatan pajak agar dapat berlangsung secara maksimal tentunya membutuhkan kesadaran masyarakat untuk mematuhi kewajiban perpajakan yang berlaku. Persoalan mengenai kepatuhan pajak telah menjadi persoalan yang penting di Indonesia karena jika wajib pajak tidak patuh maka dapat menimbulkan keinginan untuk melakukan tindakan penghindaran, pengelakan dan pelalaian pajak yang pada akhirnya akan merugikan negara yaitu berkurangnya penerimaan pajak (Mangoting, 2013). Tinggi rendahnya wajib pajak dalam mematuhi kewajiban perpajakannya dipengaruhi oleh beberapa faktor, salah satunya adalah kesadaran wajib pajak. Kesadaran masyarakat yang tinggi akan mendorong semakin banyak masyarakat memenuhi kewajibannya untuk mendaftarkan diri sebagai wajib pajak, melaporkan dan membayar pajaknya dengan benar sebagai wujud tanggungjawab berbangsa dan bernegara (James \& Nobes, 1997). Meningkatkan pengetahuan masyarakat tentang perpajakan melalui pendidikan akan membawa berdampak positif terhadap kesadaran wajib pajak untuk membayar kewajiban perpajakannya (Rohmawati 
\& Rasmini, 2012). Apabila kesadaran masyarakat atas perpajakan masih rendah maka akan menyebabkan banyaknya potensi pajak yang tidak dapat dimanfaatkan.

Ali et al. (2001) menyatakan bahwa audit dan sanksi merupakan kebijakan yang efektif untuk mencegah ketidakpatuhan. Mencegah ketidakpatuhan serta untuk mendorong wajib pajak untuk memenuhi kewajiban perpajakannya maka haruslah diberlakukan sanksi yang tegas dalam rangka untuk memajukan keadilan dan efektivitas sistem pajak (Webley et al., 1991). Sanksi perpajakan juga merupakan salah satu faktor yang memengaruhi tinggi rendahnya kepatuhan wajib pajak. Pelanggaran peraturan perpajakan akan dapat ditekan apabila terdapat sanksi perpajakan yang mengaturnya. Pandangan wajib pajak tentang banyaknya kerugian yang akan dialaminya apabila melanggar kewajiban membayar pajak akan mendorong wajib pajak untuk patuh pada kewajiban perpajakannya (Hidayat \& Nugroho, 2010).

Denpasar akan dijadikan fokus dalam melakukan penelitian terkait kepatuhan wajib pajak yang terdaftar di KPP Pratama Denpasar Timur. Sebagai informasi awal, tingkat kepatuhan wajib pajak orang pribadi di Denpasar bisa dilihat melalui tingkat pencapaian pelaporan wajib pajak orang pribadi di KPP Pratama Denpasar Timur pada Tabel 3.

Tabel 3. Tingkat Kepatuhan Wajib Pajak Orang Pribadi di KPP Pratama Denpasar Timur Tahun 2013-2017

\begin{tabular}{lllll}
\hline \multirow{2}{*}{ Tahun } & $\begin{array}{l}\text { WPOP } \\
\text { Terdaftar }\end{array}$ & $\begin{array}{l}\text { WPOP } \\
\text { Efektif }\end{array}$ & $\begin{array}{l}\text { WPOP yang } \\
\text { menyampaikan SPT }\end{array}$ & $\begin{array}{c}\text { Kepatuhan } \\
\text { (Persen) }\end{array}$ \\
\hline 2013 & 91.440 & 71.928 & 63.765 & 61,17 \\
2014 & 83.926 & 64.405 & 58.279 & 65,82 \\
2015 & 87.652 & 68.124 & 55.616 & 71,82 \\
2016 & 91.048 & 71.554 & 56.151 & 78,60 \\
2017 & 96.073 & 76.543 & 56.786 & 72,27 \\
\hline
\end{tabular}

Sumber: KPP Pratama Denpasar Timur, 2019

Berdasarkan Tabel 3. terlihat bahwa persentase kepatuhan wajib pajak orang pribadi yang berada di lingkungan KPP Pratama Denpasar Timur mengalami fluktuasi selama lima tahun terakhir. Persentase kepatuhan di tahun 2013 sebesar 61,17 persen meningkat menjadi 65,82 persen pada tahun 2014 , pada tahun 2015 menigkat menjadi 71,82 persen, pada tahun 2016 meningkat menjadi 78,60 persen, tetapi pada tahun 2017 mengalami penurunan sebesar 72,27 persen. Dapat disimpulkan, persentase kepatuhan wajib pajak orang pribadi yang terdaftar di KPP Pratama Denpasar Timur dalam rentang waktu lima tahun terakhir diatas 50 persen. Hal ini mengindikasikan bahwa tingkat kepatuhan wajib pajak cukup baik.

Sistem e-filling merupakan sebuah sistem administrasi yang digunakan dalam menyampikan SPT secara elektronik. Sistem ini menjadi salah satu inovasi yang dilakukan oleh Direktur jenderal Pajak agar Wajib pajak dapat melaporkan SPT lebih cepat dan kapan saja (Agustiningsih \& Isroah, 2016). Wajib Pajak memandang bahwa sistem ini memberikan manfaat bagi dirinya hal ini akan membentuk sebuah sikap positif dari Wajib Pajak yang selanjutnya akan meningkatkan Kepatuhan Wajib Pajak Orang Pribadi dalam melaporkan SPTnya. Penelitian yang dilakukan Rizky \& Jaya (2012) menghasilkan bahwa dengan 
adanya sistem $e$-filling ini, tingkat kepatuhan Wajib Pajak dalam pelaporan SPT dapat meningkat. Saputra (2013) hasil penelitiannya menunjukkan bahwa kualitas teknologi informasi berpengaruh terhadap kualitas pelayanan dan penerapan -filling berpengaruh positif terhadap kualitas pelayanan. Berdasarkan landasan teori dan penelitian tersebut, maka dapat dirumuskan hipotesis sebagai berikut:

$\mathrm{H}_{1}$ : E-filling berpengaruh positif pada kepatuhan Wajib Pajak Orang Pribadi.

Berdasarkan teori atribusi, kualitas pelayanan yaitu penyebab eksternal karena dilakukan oleh pihak aparat pajak sehingga dapat mempengaruhi persepsi wajib pajak dalam melakukan sikap maupun tindakan untuk melaksanakan kewajiban perpajakan. Kualitas pelayanan dinilai sebagai perbandingan antara harapan yang diinginkan oleh pelanggan dengan penilaian mereka pada kinerja aktual dari suatu penyediaan layanan (Cronin \& Taylor, 1992). Kepuasan wajib pajak sebagai pelanggan dapat ditingkatkan melalui peningkatan kualitas dan kuantitas pelayanan. Hal ini diharapkan dapat meningkatkan kepatuhan wajib pajak dalam bidang perpajakan (Supadmi, 2011). Hasil penelitian yang dilakukan oleh Jotopurnomo \& Mangoting (2013) menunjukkan bahwa kualitas pelayanan fiskus memberikan pengaruh yang signifikan terhadap kepatuhan wajib pajak orang pribadi. Berdasarkan landasan teori dan penelitian tersebut, maka dapat dirumuskan hipotesis sebagai berikut: $\mathrm{H}_{2}$ : Kualitas Pelayanan berpengaruh positif pada kepatuhan Wajib Pajak Orang Pribadi.

Kesadaran wajib pajak adalah suatu kondisi dimana wajib pajak mengetahui, memahami, dan melaksanakan ketentuan perpajakan dengan benar dan sukarela. Semakin tinggi tingkat kesadaran wajib pajak maka pemahaman dan pelaksanaan kewajiban perpajakan semakin baik sehingga dapat meningkatkan kepatuhan. Penelitian yang dilakukan oleh Dicriyani \& Budhiarta (2016) menemukan bahwa kesadaran wajib pajak berpengaruh positif dan signifikan pada kepatuhan pelaporan. Berdasarkan landasan teori dan penelitian tersebut, maka dapat dirumuskan hipotesis sebagai berikut:

$\mathrm{H}_{3}$ : Kesadaran Wajib Pajak berpengaruh positif pada kepatuhan Wajib Pajak Orang Pribadi.

Ajzen mengembangkan theory of planned behavior (TPB) ini pada tahun 1988. Ajzen (1991) menambahkan sebuah konstruk yang belum ada di TRA. Konstruk ini disebut dengan control perilaku. Konstruk ini ditambahkan di TPB untuk mengontrol perilaku individual yang dibatasi oleh kekurangankekurangannya dan keterbatsan-keterbatasan dari kekurangan sumber-sumber daya yang digunakan untuk melakukan perilakunya. Marjan (2014) hasil penelitian menunjukkan bahwa kesadaran Wajib Pajak, pelayanan fikus, dan sanksi pajak berpengaruh positif dan signifikan terhadap kepatuhan formal wajib pajak. Penelitian yang dilakukan oleh Dewi \& Merkusiwati (2018) menyatakan bahwa sanksi pajak berpengaruh positif pada kepatuhan wajib pajak. Berdasarkan landasan teori dan penelitian tersebut, maka dapat dirumuskan hipotesis sebagai berikut:

$\mathrm{H}_{4}$ : Sanksi perpajakan berpengaruh positif pada kepatuhan Wajib Pajak Orang Pribadi. 


\section{METODE PENELITIAN}

Lokasi penelitian merupakan suatu tempat atau wilayah dimana penelitian tersebut akan dilakukan. Wilayah kerja KPP Pratama Denpasar Timur adalah Kecamatan Denpasar Timur dan Kecamatan Denpasar Selatan. Kecamatan Denpasar Timur terdiri atas sebelas desa/kelurahan, yaitu Desa Dangin Puri Klod, Desa Penatih Dangin Puri, Desa Sumerta Kaja, Desa Sumerta Kauh, Desa Kesiman Kertalangu, Desa Sumerta Klod, Desa Kesiman Petilan, Kelurahan Dangin Puri, Kelurahan Kesiman, Kelurahan Penatih, dan Kelurahan Sumerta. Sementara itu, Kecamatan Denpasar Selatan terdiri atas sepuluh desa/kelurahan, yaitu Desa Pemogan, Desa Sanur Kaja, Desa Sanur Kauh, Desa Sidakarya, Kelurahan Panjer, Kelurahan Pedungan, Kelurahan Renon, Kelurahan Sanur, Kelurahan Serangan, Kelurahan Sesetan. Adapun batas wilayah kerja KPP Pratama Denpasar Timur adalah Kecamatan Denpasar Utara dan Kecamatan Denpasar Barat di sebelah utara, Kecamatan Sukawati, Gianyar, dan Selat Badung di sebelah timur, Kecamatan Kuta, Badung, dan Selat Badung di sebelah selatan, dan Kecamatan Kuta, Badung, dan Kecamatan Denpasar Barat di sebelah barat.

Penelitian dilaksanakan di KPP Pratama Denpasar Timur, dengan alamat Jl. Tantular No.4, Renon, Kec. Denpasar Timur., Kota Denpasar, Bali 80234. KPP Pratama merupakan KPP yang menangani wajib pajak terbanyak, serta KPP Pratama memiliki fungsi utama melaksanakan penyuluhan, pelayanan, dan pengawasan wajib pajak dibidang PPh, PPN, PPnBM, dan Pajak Tidak Langsung lainnya dalam wilayah wewenangnya sesuai perundang-undangan yang berlaku, maka dari hal ini lokasi penelitian dipilih di KPP Pratama Denpasar Timur.

Populasi dalam penelitian ini adalah seluruh wajib pajak orang pribadi yang tercatat di KPP Pratama Denpasar Timur. Jumlah populasi dalam penelitian ini yaitu 5.032 orang wajib pajak orang pribadi. Guna efisiensi waktu dan biaya, maka tidak semua wajib pajak tersebut menjadi objek dalam penelitian ini. Pengambilan sampel dalam penelitian ini dilakukan dengan menggunakan metode simple random sampling. Sampelnya adalah orang-orang yang ditemui oleh peneliti secara acak. Penentuan sampel ditentukan dengan menggunakan rumus Slovin, maka diperoleh jumlah sampel sebanyak 100 responden. Penggunaan sampel ini bertujuan untuk memperoleh efisien dalam hal tenaga, waktu, dan biaya. Rumus Slovin yang digunakan untuk mengukur jumlah sampel sebagai berikut.

$$
\mathrm{N}=\frac{\mathrm{N}}{\mathbf{1 + (}\left(\mathrm{Ne}^{2}\right)}
$$

$\mathrm{n}=$ jumlah sampel

$\mathrm{N}=$ populasi

$\mathrm{e}=$ persen kelonggaran ketidak telitian karena kesalahan pengambilan sampel yang masih dapat ditolerir atau diinginkan, dalam penelitian ini adalah 0,1.

Berdasarkan data dari KPP Pratama Denpasar Timur, hingga akhir tahun 2017 sebanyak 76.543 wajib pajak orang pribadi yang merupakan wajib pajak orang pribadi efektif. Maka jumlah sampel untuk penelitian dengan margin of error sebesar 0,1 . 


$$
\begin{gathered}
n=\frac{76.543}{1+\left(76.543(0.1)^{2}\right)} \\
n=99,86(\text { dibulatkan } 100)
\end{gathered}
$$

Berdasarkan perhitungan, maka jumlah sampel yang diambil dalam penelitian ini adalah sebanyak 100 sampel wajib pajak orang pribadi di KPP Pratama Denpasar Timur.

Teknik analisis yang digunakan dalam penelitian ini adalah analisis regresi berganda. Pelayanan Pajak Madya Denpasar. Berikut model regresi dalam penelitian ini:

$Y=\alpha+\beta_{1} X_{1}+\beta_{2} X_{2}+\beta_{3} X_{3}+\beta_{4} X_{4}+e$

Keterangan:

$\mathrm{Y}=$ Kepatuhan wajib pajak

$\alpha=$ Konstanta

$\beta=$ Koefisien regresi

$\mathrm{e}=$ Standar error

$$
\begin{gathered}
X_{1}=\text { Pengaruh } e-f i l l i n g \\
X_{2}=\text { Kualitas Pelayanan Wajib Pajak } \\
X_{3}=\text { Kesadaran Wajib Pajak } \\
X_{4}=\text { Sanksi Perpajakan }
\end{gathered}
$$

\begin{tabular}{|c|c|c|c|c|c|c|}
\hline \multirow{2}{*}{\multicolumn{2}{|c|}{ Model }} & \multicolumn{3}{|c|}{$\begin{array}{r}\text { Standardized } \\
\text { Unstandardized CoefficientsCoefficients }\end{array}$} & & \multirow[b]{2}{*}{ Sig. } \\
\hline & & $\mathrm{B}$ & Std. Error & Beta & $\mathrm{t}$ & \\
\hline \multirow[t]{5}{*}{1} & (Constant) & 1.042 & 1.013 & & 1.029 & .306 \\
\hline & Penerapan E-Filling & .088 & .029 & 195 & 3.083 & .003 \\
\hline & Kualitas Pelayanan & .178 & .033 & .456 & 5.444 & .000 \\
\hline & Kesadaran Wajib Pajak & .174 & .077 & 159 & 2.254 & .027 \\
\hline & Sanksi Perpajakan & .179 & .060 & .209 & 2.969 & .004 \\
\hline
\end{tabular}

\section{HASIL DAN PEMBAHASAN}

Perhitungan koefisien regresi linier berganda dilakukan dengan analisis regresi melalui software SPSS 18.0 for Windows, diperoleh hasil yang ditunjukan pada Tabel 4.

Tabel 4. Hasil Analisis Regresi Linier Berganda

Sumber: Data Penelitian, 2019

Berdasarkan hasil analisis regresi linier berganda seperti yang disajikan pada Tabel 3, maka dapat dibuat persamaan regresi sebagai berikut.

$$
Y=1,042+0,088 X_{1}+0,178 X_{2}+0,174 X_{3}+0,179 X_{4}
$$

Nilai koefisien regresi masing-masing variabel bebas bernilai positif dengan nilai signifikansi uji t kurang dari 0,05. Hal ini menunjukkan bahwa semua variabel bebas memiliki pengaruh positif yang signifikan terhadap variabel terikat. Berikut penjelasan mengenai hasil analisis regresi berganda, terdiri atas koefisien determinasi $\left(\mathrm{R}^{2}\right)$, uji kelayakan model (uji $\mathrm{F}$ ), dan uji hipotesis (uji t).

Koefisien determinasi $\left(\mathrm{R}^{2}\right)$ digunakan untuk mengetahui dan mengukur kemampuan model dalam menerangkan variasi variabel independen. Besarnya pengaruh variabel bebas terhadap variabel terikat yang ditunjukkan oleh nilai determinasi total (R Square). Adapun hasil uji koefisien determinasi dalam penelitian ini dapat dilihat pada Tabel 5. 
Tabel 5. Hasil Uji Koefisien Determinasi $\left(\mathbf{R}^{2}\right)$

\begin{tabular}{clllllr}
\hline Model & & & & Std. Error of the \\
& $\mathrm{R}$ & R Square & Adjusted $R$ Square & Estimate & \\
\hline 1 & $.913^{\mathrm{a}}$ & .834 & .827 & 1.19423 & \\
\hline
\end{tabular}

Sumber: Data Penelitian, 2019

Nilai R Square sebesar 0,834 mempunyai arti bahwa sebesar 83,44\% variasi kepatuhan wajib pajak dipengaruhi oleh variasi penerapan e-filling, kualitas pelayanan, kesadaran wajib pajak, dan sanksi perpajakan, sedangkan sisanya sebesar 16,6\% djelaskan oleh faktor lain yang tidak dimasukkan ke dalam model.

Uji kelayakan model regresi bertujuan untuk mengetahui apakah semua variabel bebas yang diidentifikasi (penerapan e-filling, kualitas pelayanan, kesadaran wajib pajak, dan sanksi perpajakan,) tepat digunakan memprediksi kepatuhan wajib pajak. Uji ini sering juga disebut dengan uji F. Adapun hasil uji F dapat dilihat pada Tabel 6.

Tabel 6. Hasil Uji Kelayakan Model (Uji F)

\begin{tabular}{|c|c|c|c|c|c|}
\hline$\overline{\text { Model }}$ & Sum of Squares & $\overline{D f}$ & Mean Square & $\bar{F}$ & Sig. \\
\hline 1 Regression & 679.103 & 4 & 169.776 & 119.042 & $.000^{a}$ \\
\hline Residual & 135.487 & 95 & 1.426 & & \\
\hline Total & 814.590 & 99 & & & \\
\hline
\end{tabular}

Sumber: Data Penelitian, 2019

Hasil pengolahan data dengan menggunakan program SPSS pada Tabel 6. menunjukkan nilai $F_{\text {hitung }}$ sebesar 119,042 dengan signifkansi sebesar 0,000 < 0,05, maka dapat disimpulkan bahwa pada kelompok yang diuji memiliki perbedaan yang nyata (signifikan). Hasil ini mempunyai arti bahwa secara simultan variabel penerapan e-filling, kualitas pelayanan, Kesadaran Wajib Pajak, dan sanksi perpajakan berpengaruh signifikan terhadap kepatuhan wajib pajak.

Pengaruh variabel penerapan e-filling, kualitas pelayanan, Kesadaran Wajib Pajak, dan sanksi perpajakan terhadap kepatuhan wajib pajak diuji dengan menggunakan Uji t. Kriteria pengujian untuk menjelaskan interpretasi pengaruh antar masing-masing variabel yakni apabila nilai signifikansi $<0,05$ maka $\mathrm{H}_{0}$ ditolak dan $\mathrm{H}_{1}$ diterima. Sebaliknya, jika nilai signifikansi $>0,05$ maka $\mathrm{H}_{0}$ diterima dan $\mathrm{H}_{1}$ ditolak.

Berdasarkan Tabel 4. hasil analisis pengaruh penerapan $e$-filling terhadap kepatuhan wajib pajak diperoleh nilai signifikasi sebesar 0,003 dengan nilai koefisien regresi positif sebesar 0,088. Nilai Signifikansi 0,003<0,05 mengindikasikan bahwa $\mathrm{H}_{1}$ diterima. Hasil ini mempunyai arti bahwa penerapan e-filling berpengaruh positif dan signifikan terhadap kepatuhan wajib pajak. Berdasarkan Tabel 3, hasil analisis pengaruh kualitas pelayanan terhadap kepatuhan wajib pajak diperoleh nilai signifikansi sebesar 0,000 dengan nilai koefisien regresi positif sebesar 0,178. Nilai Signifikansi 0,000<0,05 mengindikasikan bahwa $\mathrm{H}_{2}$ diterima. Hasil ini mempunyai arti bahwa kualitas pelayanan berpengaruh positif dan signifikan terhadap kepatuhan wajib pajak.

Berdasarkan Tabel 4. hasil analisis pengaruh Kesadaran Wajib Pajak terhadap kepatuhan wajib pajak diperoleh nilai signifikansi sebesar 0,027 dengan nilai koefisien regresi positif sebesar 0,174. Nilai signifikansi 0,027 <0,05 mengindikasikan bahwa $\mathrm{H}_{3}$ diterima. Hasil ini mempunyai arti bahwa 
Kesadaran Wajib Pajak berpengaruh positif dan signifikan kepatuhan wajib pajak.

Berdasarkan Tabel 4. hasil analisis pengaruh sanksi perpajakan terhadap kepatuhan wajib pajak diperoleh nilai signifikansi sebesar 0,004 dengan nilai koefisien regresi positif sebesar 0,178. Nilai signifikansi 0,004<0,05 mengindikasikan bahwa $\mathrm{H}_{4}$ diterima. Hasil ini mempunyai arti bahwa sanksi perpajakan berpengaruh positif dan signifikan terhadap Kepatuhan wajib pajak.

Penerapan e-filling dalam hasil pengujian hipotesis ini berpengaruh positif terhadap kepatuhan wajib pajak. Hal ini dibuktikan dari diterapkannya sistem e-filling dalam melaporkan SPTnya kapan saja dan dimana saja. Selain itu, penerapan e-filling akan menghemat biaya, menghemat waktu, melakukan perhitungan pajak lebih mudah secara cepat dan akurat, serta tidak perlu mencetak semua formulir lampiran untuk dilaporkan ke kantor pajak.

Hasil penelitian sebelumnya yang dilakukan oleh Saputra (2013) menunjukkan bahwa kualitas teknologi informasi berpengaruh terhadap kualitas pelayanan dan penerapan e-filling berpengaruh positif terhadap kualitas pelayanan. Agustiningsih \& Isroah (2016) juga menyatakan bahwa penerapan sistem e-filing berpengaruh positif terhadap kepatuhan wajib pajak. Konsep Theory of Planned Behavior menjadi dasar dalam hipotesis penelitian, menyatakan bahwa penerapan e-filling dalam membayar pajak dapat ditentukan oleh perilaku individu itu sendiri serta ditentukan oleh niat. Selain itu, konsep Teori Pembelajaran Sosial menekankan pada bagaimana individu dapat berpikir dan memiliki pemahaman dalam penerapan $e$-filling dalam proses pembayaran pajak.

Kualitas pelayanan dalam hasil pengujian hipotesis ini diketahui berpengaruh positif terhadap kapatuhan wajib pajak. Hal ini dibuktikan juga dari kondisi kualitas pelayanan di KPP Pratama Denpasar Timur yang dilihat dari kondisi gedung, teknologi, kondisi ruang tunggu, dan fasilitas yang ada. Begitu pula dengan pelayanan yang diberikan oleh petugas pajak dalam memberi penjelasan atau menjawab pertanyaan wajib pajak, memberi kepuasan dan pemahaman bagi wajib pajak.

Hasil penelitian sebelumnya yang dilakukan oleh peneliti terdahulu juga membuktikan bahwa kualitas pelayanan berpengaruh positif terhadap kepatuhan wajib pajak. Probondari (2013), Putri \& Setiawan (2017) dan Syahril (2013) memperoleh hasil bahwa kualitas pelayanan berpengruh positif terhadap kepatuhan wajib pajak. Konsep Theory of Planned Behavior yang menjadi dasar dalam hipotesis penelitian, menyatakan bahwa perilaku individu untuk patuh pada ketentuan perpajakan ditentukan oleh niat seseorang. Niat tersebut muncul dari dalam diri wajib pajak yang dapat menjadi faktor yang menentukan seseorang untuk berperilaku. Selain itu, konsep dari Teori Pembelajaran Sosial menekankan pada komponen kognitif dari pikiran, pemahaman, dan evaluasi.

Kesadaran wajib pajak dalam hasil pengujian hipotesis ini diketahui berpengaruh positif terhadap kepatuhan wajb pajak. Hal ini dibuktikan dari kesadaran wajib pajak untuk memenuhi kewajiban dalam membayar pajak, selain terdapat Undang-Undang perpajakan yang ditetapkan agar wajib pajak taat dalam membayar pajak. Kesadaran wajib pajak dapat memberi kemajuan atau kesejahteraan rakyat. 
Hasil penelitian sebelumnya yang dilakukan oleh peneliti terdahulu juga membuktikan bahwa kesadaran wajib pajak berpengaruh positif terhadapat kepatuhan wajib pajak. Dicriyani \& Budiartha (2016), Megawangi \& Setiawan (2017) menyatakan bahwa kesadaran wajib pajak berpengaruh positif pada kepatuhan pelaporan. Selain itu, Muliari \& Ery Setiawan, (2011) juga menyatakan bahwa kesadaran wajib pajak berpengaruh yang signifikan dan positif terhadap kepatuhan wajib pajak, serta Astana \& Merkusiawati (2017) juga menunjukkan bahwa adanya pengaruh positif antara kesadaran wajib pajak terhadap kepatuhan wajib pajak orang pribadi. Konsep Theory of Planned Behavior menyatakan bahwa perilaku individu untuk patuh pada ketentuan perpajakan ditentukan oleh niat seseorang dan kesadaran seseorang. Selain itu konsep Teori Pembelajaran Sosial juga menjadi dasar dalam segi pemikiran untuk bagaimana seseorang memiliki kesadaran untuk membayar pajak.

Sanksi perpajakan dalam hasil pengujian hipotesis ini diketahui berpengaruh positif pada kepatuhan wajib pajak. Hal ini dibuktikan dari adanya sanksi perpajakan berupa denda membuat wajib pajak taat dalam membayar pajak. Hasil penelitian sebelumnya yang dilakukan oleh peneliti terdahulu juga membuktikan bahwa sanksi perpajakan berpengaruh positif pada kepatuhan wajib pajak. Dewi \& Merkusiwati (2018) menyatakan bahwa sanksi perpajakan berpengaruh positif pada kepatuhan wajib pajak. Arum (2012) juga menyatakan bahwa terdapat pengaruh positif antara sanksi perpajakan terhadap kepatuhan pelaporan wajib pajak. Konsep Theory of Planned Behavior menyatakan bahwa perilaku individu untuk patuh pada ketentuan perpajakan ditentukan oleh niat. Selain itu, konsep Teori Pembajaran Sosial juga turut mendasari dari perilaku individu melalui pemikiran dan pemahanan terhadap pentingnya membayar pajak dengan adanya sanksi perpajakan.

\section{SIMPULAN}

Penerapan e-filling berpengaruh positif pada kepatuhan wajib pajak orang pribadi yang terdaftar di KPP Pratama Denpasar Timur. Penerapan e-filling ini sangat membantu mempermudah dalam membayar pajak bagi wajib pajaknya, semakin baik penerapan e-filling yang diberikan oleh petugas pajak, maka kepatuhan wajib pajak juga akan meningkat. Kualitas pelayanan berpengaruh positif pada kepatuhan wajib pajak orang pribadi yang terdaftar di KPP Pratama Denpasar Timur. Kuliatas pelayanan dapat berikan kepada wajib pajak berupa pelayanan yang baik dari petugas pajak serta fasilitas yang memadai dapat meningkatkan kapatuhan wajib pajak mengenai kewajiban perpajakannya. Semakin baik kualitas pelayanan yang diberikan, kepatuhan wajib pajak dalam melaksanakan kewajiban perpajakannya akan semakin baik. Kesadaran wajib pajak berpengaruh positif pada kepatuhan wajib pajak orang pribadi yang terdaftar di KPP Pratama Denpasar Timur. Wajib pajak yang sadar melaksanakan kewajiban perpajakannya akan meningkatkan kepatuhan wajib pajak tersebut, dengan kesadaran untuk memenuhi kewajiban perpajakan dapat memberi kemajuan atau kesejahteraan rakyat. Sanksi perpajakan berpengaruh positif pada kepatuhan wajib pajak orang pribadi yang terdaftar di KPP Pratama Denpasar Timur. Sanksi perpajakan ini dapat meningkatkan kepatuhan wajib pajak dalam memenuhi kewajiban perpajakannya. Semakin tinggi atau beratnya 
sanksi perpajakan ini, maka wajib pajak akan lebih taat dalam hal kewajiban perpajakannya.

\section{REFERENSI}

Agustiningsih, W., \& Isroah, I. (2016). Pengaruh Penerapan E-Filing, Tingkat Pemahaman Perpajakan Dan Kesadaran Wajib Pajak Terhadap Kepatuhan Wajib Pajak Di Kpp Pratama Yogyakarta. Nominal, Barometer Riset Akuntansi Dan Manajemen, 5(2), 107-122. https://doi.org/10.21831/nominal.v5i2.11729

Ajzen, I. (1991). The Theory of Planned Behavior. Organizational Behavior and Human Decision Processes, 50(2), 179-211.

Ali, M. M., Cecil, H. W., \& Knoblett, J. A. (2001). The effects of tax rates and enforcement policies on taxpayer compliance: A study of selfemployed taxpayers. Atlantic Economic Journal, 29(2), 186-202. https://doi.org/10.1007/BF02299137

Arum, H. P. (2012). 2012. Pengaruh Kesadaran Wajib Pajak, Pelayanan Fiskus, dan Sanksi Pajak terhadap Kepatuhan Wajib Pajak Orang Pribadi yang Melakukan Kegiatan Usaha dan Pekerjaan Bebas (Studi di Wilayah KPP Pratama Cilacap). Skripsi. Sarjana Jurusan Akuntansi Fakultas Ekonomika dan Bisnis Universitas Diponegoro.

Astana, I. W. S., \& Merkusiawati, N. K. L. A. (2017). Pengaruh Penerapan Sistem Administrasi Perpajakan Modern, Kualitas Pelayanan Dan Kesadaran Wajib Pajak Pada Kepatuhan WPOP. E-Jurnal Akuntansi Universitas Udayana, 18(1), 818-846. https://doi.org/10.24843/eja.2019.v26.i01.p09

Chau, G., \& Leung, P. (2009). A Critical Review of Fischer's Tax Compliance Model: A Research Systhesis. International Accounting, Auditing and Taxation, 1(2), 34-40. Retrieved from http://www.sciencedirect.com/science/article/pii/S106195180000 0276

Cronin, J. J., \& Taylor, S. A. (1992). Measuring Service Quality: A Reexamination and Extension. Journal of Marketing, 56(3), 55. https://doi.org/10.2307/1252296

Dewi, G. A. P. I. P., \& Merkusiwati, N. K. L. A. (2018). Faktor-Fator yang Memengaruhi Tingkat Kepatuhan Wajib Pajak Orang Pribadi di KPP Pratama Badung Utara. E-Jurnal Akuntansi Universitas Udayana, 23(2), 1277-1304. https://doi.org/10.24843/eja.2018.v23.i02.p18

Dicriyani, N. L. G. M., \& Ketut, B. I. (2016). Pengaruh Kualitas Pelayanan dan Pengetahuan Perpajakan Pada Perilaku Kepatuhan Wajib Pajak Dengan Niat Sebagai Pemoderasi. E-Jurnal Ekonomi Dan Bisnis Universitas Udayana, 10, 3329-3358.

Hidayat, W., \& Nugroho, A. A. (2010). Studi Empiris Theory of Planned Behavior Ketidakpatuhan Pajak Wajib Pajak Orang Pribadi. Jurnal Akuntansi Dan Keuangan, 12(2), 82-93. https://doi.org/10.1097/00042737200205000-00005 
Idawati, I. (2012). Factors Underpinning Usage Behaviour of an Electronic Filing System: The Case of Malaysian Personal Taxpayers. International Journal of Asian Social Science, 4(3), 1-21.

James, S., \& Nobes, C. (1997). The Economic of Taxation, Principle, Policy and Practice. Europe: Prentice Hall.

Jotopurnomo, C., \& Mangoting, Y. (2013). Pengaruh Kesadaran Wajib Pajak, Kualitas Pelayanan Fiskus, Sanksi Perpajakan, Lingkungan Wajib Pajak Berada terhadap Kepatuhan Wajib Pajak Orang Pribadi di Surabaya. Tax \& Accounting Review, 1(1), 49-54.

Lai, M.-L., \& Choong, K.-F. (2009). Self-assessment Tax System and Compliance Complexities: Tax Practicioner's Perspectives. Oxford Busines $\mathcal{E}$ Economics Conference, 1-20.

Laihad, R. C. Y. (2013). Pengaruh Perilaku Wajib Pajak Terhadap Penggunaan EFiling Wajib. Jurnal Emba: Jurnal Riset Ekonomi, Manajemen, Bisnis Dan Akuntansi, 1(3), 44-51.

Mangoting, A. O. F. dan Y. (2013). Pengaruh Kualitas Pelayanan Petugas Pajak, Sanksi Perpajakan dan Biaya Kepatuhan Pajak Terhadap Kepatuhan Wajib Pajak UMKM. Tax \& Accounting Review, 1(1), 18-27.

Marjan, R. M. (2014). Pengaruh Kesadaran Wajib Pajak, Pelayanan Fiskus, dan Sanksi Pajak terhadap Tingkat Kepatuhan Formal Wajib Pajak (Studi di Kantor Pelayanan Pajak Pratama Makassar Selatan). Skripsi .Jurusan Akuntansi Fakultas Ekonomi dan Bisnis Universitas Hasanuddin. Universitas Hasanuddin.

Megawangi, C. A. M., \& Setiawan, P. E. (2017). Sosialisasi Perpajakan Memoderasi Pengaruh Kesadaran Wajib Pajak Dan Kualitas Pelayanan Pada Kepatuhan Wajib Pajak Badan. E-Jurnal Akuntansi Universitas Udayana, 19(3), 2348-2377.

Muliari, N. K., \& Ery Setiawan, P. (2011). Pengaruh Persepsi Tentang Sanksi Perpajakan Dan Kesadaran Wajib Pajak Pada Kepatuhan Pelaporan Wajib Pajak Orang Pribadi di Kantor Pelayanan Pajak Pratama Denpasar Timur. Jurnal Ilmiah Akuntansi Dan Bisnis, 6(1), 1-23.

Nur Rohmawati, A., \& Rasmini, N. (2012). Pengaruh Kesadaran, Penyuluhan, Pelayanan, Dan Sanksi Perpajakan Pada Kepatuhan Wajib Pajak Orang Pribadi. E-Jurnal Akuntansi Universitas Udayana, 1(2), 1-17.

Probondari, R. (2013). Faktor-Faktor Yang Mempengaruhi Kemauan Membayar Pajak Oleh Wajib Pajak Orang Pribadi Yang Terdaftar Di Kantor Pelayanan Pajak Pratama Bintan. Skripsi. Sarjana Jurusan Akuntansi Fakultas Ekonomi Universitas Maritim Raja Ali Haji Tanjungpinang.

Putri, K. J., \& Setiawan, P. E. (2017). Pengaruh Kesadaran, Pengetahuan dan Pemahaman Perpajakan, Kualitas Pelayanan dan Sanksi Perpajakan terhadap Kepatuhan Wajib Pajak. E-Jurnal Akuntansi Universitas Udayana, 18(2), 1112-1140.

Rizky, S. A., \& Jaya, T. E. (2012). Pengaruh persepsi penerapan sistem e-filling terhadap Tingkat Kepatuhan Wajib Pajak Badan dengan Perilaku Wajib Pajak sebagai Variabel Intervening dan Biaya Kepatuhan sebagai Variabel Moderasi. Skripsi. Sarjana Jurusan Akuntansi Fakultas Ekonomi Universitas Negeri Jakarta. 
Saputra, E. N. (2013). Pengaruh Kualitas Teknologi Informasi dan Penerapan EFillinf terhadap Kualitas Pelayanan. Journal of Chemical Information and Modeling, 53(9), 1689-1699. https://doi.org/10.1017/CBO9781107415324.004

Supadmi, N. luh. (2011). Meningkatkan Kepatuhan Wajib Pajak Melalui Kualitas Pelayanan. Jurnal Ilmiah Akuntansi, 4(2), 1-14.

Syahril, F. (2013). Pengaruh Tingkat Pemahaman Wajib Pajak dan Kualitas Pelayanan Fiskus Terhadap Tingkat Kepatuhan Wajib Pajak PPh Orang Pribadi (Studi Empiris pada KPP Pratama Kota Solok). Jurnal Akuntansi, 1(2), 1-25. Retrieved from http://ejournal.unp.ac.id/students/index.php/akt/article/viewFil e/902/652

Webley, P., Robben, H., Elffers, H., \& Hessing, D. (1991). Tax Evasion: An Experimental Approach. United Kingdom: Cambridge University Press. 